AASA TIPI- B3569

NASA

Technical Memorandum 83569
USAAVSCOM

Technical Report 84-C-1

\title{
Comparison of Icing Cloud Instruments for 1982-1983 Icing Season Flight Program
}

\author{
NASA-TM-83569 \\ $198 \times 10021801$
}

Robert F. Ide

Propulsion Laboratory

AVSCOM Research and Technology Laboratories

Lewis Research Center

Cleveland, Ohio

and

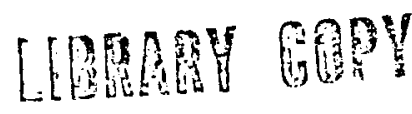

G. Paul Richter

Lewis Research Center

Cleveland, Ohio

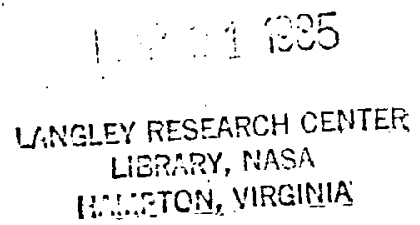

Prepared for the

Twenty-second Aerospace Sciences Meeting

sponsored by the American Institute of Aeronautics and Astronautics

Reno, Nevada, January 9-12, 1984

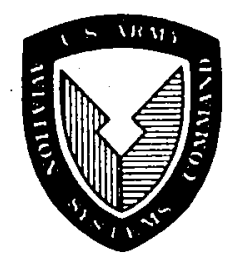


Trade names or manufacturers' names are used in this report for identification only. This usage does not constitute an official endorsement, either expressed or implied, by the National Aeronautics and Space Administration. 
COMPARISON OF ICING CLOUD INSTRUMENTS FOR 1982 - 1983

ICING SEASON FLIGHT PROGRAM

\author{
Robert F. Ide \\ Propulsion Laboratory \\ AVSCOM Research and Technology Laboratories \\ and \\ G. Paul Richter \\ National Aeronautics and Space Administration \\ Lewis Research Center \\ Cleveland, Ohio 44735
}

\title{
I. SUMMARY
}

A number of modern and old-style liquid water content (LHC) and droplet sizing instruments were mounted on a DeHavilland DHC-6 Twin Otter and operated in natural icing clouds in order to determine their comparative operating characteristics and limitations over a broad range of conditions. The evaluation period occurred during the 1982-1983 "icing season" from January to March 1983. Twelve icing research flights were conducted. Time histories of all instrument outputs were plotted to assess instrument repeatability and reliability. Scatter plots were generated for comparison of the instruments.

The measured liquid water content (LWC) from four instruments differed by as much as 20 percent. The measured droplet size from two instruments differed by an average of 3 microns.

The overall effort demonstrated the need for additional comparative data, and for some means of calibrating these instruments to known standards. The importance of pre-flight instrument checks is discussed and a portable spray rig for checkout of hot-wire LWC instruments and laser spectrometers is described.

\section{INTRODUCTION}

The renewed interest in the problem of aircraft icing has brought about an expanded operation of facilities which simulate icing cloud environments, in which applicable research testing can be conducted. This, in turn, has encouraged a re-examination of the ability of various ground facilities to realistically duplicate the range of icing cloud parameters occurring in natural icing encounters.

The NASA Lewis Research Center 6 by $9 \mathrm{ft}$ Icing Research Tunnel (IRT) is one of the major icing research facilities avallable for government, industry, and university-sponsored aircraft icing research programs (ref. 1). A comparative measurement of the IRT icing cloud parameters, including liquid water content (LWC), cloud droplet size, and droplet size distribution was recently conducted to determine the relative accuracy of a number of modern and oldstyle instruments (ref. 2). As useful as this information was, it was determined that an evaluation of available icing instruments in the IRT-simulated cloud, followed by comparable operation in naturally occurring clouds was necessary. Therefore, an icing research flight program was initiated during the 
1981-1982 icing season, with the objectives of (1) conducting a comparative evaluation of avallable fcing cloud instrumentation, including modern state-ofthe-art systems and those systems and techniques already in use for some years, and (2) providing a flying research facility for conducting other icing-related experimental programs. A DeHavilland of Canada DHC-6 Twin 0tter aircraft was obtained from NASA-Langley Research Center and outfitted with a selected array of instrumentation for carrying out this effort, which was continued during the 1982-1983 icing season.

This paper will present and discuss the experimental data obtained during the initial efforts to meet the objectives discussed above and will review the areas where additional work is required.

Section 3 presents a summary of the instruments utilized and the arrangement of these instruments on the Twin otter. A description of the test procedures followed is presented in Section 4. Problems encountered during testing are also discussed. A description of the data obtained is presented in Section 5. The results of the analyses are presented and discussed in Section 6 , with conclusions and recommendations following in Section 7 .

The authors wish to acknowledge the cooperative efforts extended by the personnel at Langley Research Center in providing the Twin otter aircraft to carry out these efforts.

\section{TEST INSTRUMENTATION}

This section contains a brief description of each instrument.

1. The JOHNSON-WILLIAMS (J-W) Liquid Water Content Indicator (fig. 1(a)), uses two hot-wires in a balanced bridge circuit to measure the cloud liquid water content. The main sensing wire is mounted perpendicular to the airstream and is heated at a constant voltage to a temperature above the bolling point of water. Cloud droplets impinging on the wire are evaporated, causing the wire to cool and its electrical resistance to decrease. This change in resistance causes an imbalance in the bridge circuit; the degree of imbalance is related to the liquid water content.

A compensating wire is mounted parallel to the airstream and is not normaliy subject to cooling from droplet impingement. This wire is connected in the opposite side of bridge circuit and compensates for small variations in airspeed, altitude and air temperature. LWC is displayed on a panel meter.

2. The ROSEMOUNT ICE DETECTOR (fig. I(b)) is an ice accretion type instrument. The sensing element is a cylinder, $2.54 \mathrm{~cm}(1.0 \mathrm{in.})$ long and $0.635 \mathrm{~cm}(0.25 \mathrm{in.})$ in diameter, which is driven to vibrate axially at a resonant frequency of $40 \mathrm{KHz}$. As ice accumulates on the exposed cylinder, the effective mass of the sensing cylinder plus ice increases, thereby causing a decrease in resonant frequency. When the frequency decreases by $200 \mathrm{~Hz}$, a heater is energized, which melts the ice on the sensing element. The heater time is fixed at approximately $6 \mathrm{sec}$. The time between "heater off" and "heater on" is used to calculate icing rate and liquid water content.

3. The PRESSURE ICE RATE AND ACCRETION METER (PIRAM) (fig. $1(\mathrm{c})$ ), is an ice accretion-type instrument originally developed by NACA in the 1950's. The 
instrument has recently been modified with the addition of a microprocessor/ controlier and a real time readout package. The PIRAM operates on a differential pressure technique. The sensor is composed of a "U" shaped tubular probe. The small bridge section is a $0.25 \mathrm{~cm}(0.100 \mathrm{in.})$ diameter phosphor-bronze tube with $10 \mathrm{smal1}(0.04 \mathrm{~cm}(0.016 \mathrm{in.})$ diameter) holes drilled in its forward face. When no ice is present, these holes sense the total air pressure. The pressure from the small sensing holes is fed to one side of two differential pressure switches. The airstream total pressure is fed to the other side of these switches. As ice accretes on the sensing tube, it gradually blocks the small holes, decreasing the pressure on this side of the switches, which is bled to static pressure through a small orifice. When this pressure decreases to a fixed value a deice heater is activated which melts the ice off the probe. The icing rate and liquid water content are calculated from the time required for the differential pressure to change between two fixed levels. The icing rate, liquid water content, or total ice accretion can be displayed on a digital panel meter.

4. The LEIGH ICE DETECTOR (fig. $1(d)$ ) is an ice-accretion type instrument which was originally designed for helicopter use. An air injector pulls a continuous sample of air through the cylindrical probe. A small, $0.3 \mathrm{~cm}$ tube with a flattened front surface is placed across the inside of the probe. An infrared light beam is projected across the flat surface of this tube, and is detected by a phototransistor mounted on the other side of the cylinder. As ice accretes on the flattened face of the tube, it starts to block the light beam, decreasing the intensity seen by the phototransistor. The initial decrease in measured intensity activates a light to signal that icing has started and starts a timer. Once the ice reaches a predetermined thickness as measured by a preset intensity decrease limit, the ice is melted from the tube and the cycle starts again. The time required to accrete a predetermined thickness of ice is used by a microprocessor to compute liquid water content which is continuously displayed on a panel meter.

5. The CSIRO-KING Liquid Water Content Meter (fig. 1(e)) is a hot-wire probe. The sensor is composed of three wire colls $(0.79 \mathrm{~cm}$ diameter) wound around a small tube. The slave colls on each side of the master coil minimize the longitudinal heat conduction from the master coil. The coils are placed in a balanced bridge circuit and heated to a surface temperature of approximately $90^{\circ} \mathrm{C}\left(194^{\circ} \mathrm{F}\right)$. Prior to entering a cloud the system is "zeroed" to the existing airspeed, altitude, and temperature conditions. Upon entering a cloud, the impinging water droplets cause an increase in the wire coil heat loss rate, requiring more power to maintain the constant temperature. This increase in power is converted to liquid water content, which is displayed on a panel meter.

6. The FORWARD SCATTERING SPECTROMETER PROBE (FSSP) (fig. 2(a)), is a laser-type single-particle sizing instrument that measures particles with diameters of 0.5 to $47 \mathrm{rm}$. A focused laser beam is used to illuminate particles passing through a cylindrical sampling tube. The forward scattered light from an flluminated particle is gathered by collecting optics and focused onto a photodetector. The intensity of this light is related to the size of the particle. A second masked photodetector is used to define a narrow depth of field. The probe used in this program was equipped to measure probe activity level and total strobe counts.

7. The OPTICAL ARRAY PROBE (OAP) (fig. 2(b)) is a laser-type singleparticle sizing instrument that measures particles with diameters of 20 to 
$300 \mu \mathrm{m}$. A collimated laser beam is used to flluminate particles passing between the optic tubes. The shadow image of the particle is projected onto a linear 24 element diode array. The number of diodes shadowed, the diode spacing and the system magnification are used to define the particle size.

8. The ROTATING MULTICYLINDERS (fig. 3(a)) used in this program consisted of six cylinders with diameters of $15.24,11.43,7.62,3.18,1.27$, and $0.32 \mathrm{~cm}$ $(6,4.5,3,1.25,0.5$, and 0.125 in., respectively) mounted on a single rotating rod. The principal behind this method for determining liquid water content and mean effective drop diameter is that the collection efficiency for each cylinder size is a known function of droplet size and velocity. The chilled rotating cylinders are exposed to the cloud and approximately $0.32 \mathrm{~cm}$ of ice is allowed to accrete on the $0.32 \mathrm{~cm}$ cylinder. The exposure period, true airspeed and weight of ice on each cylinder is used in the analysis to determine liquid water content and droplet mean effective diameter. A complete description of this method is contained in reference 3 .

9. The SINGLE ROTATING CYCLINDER used in this program was a $0.32 \mathrm{~cm}$ ( 0.125 in.) diameter cylinder (the smallest cylinder of the rotating multicylinder stack). It is exposed in the same manner as the rotating multicylinders. The exposure period, true airspeed and weight of ice on the cylinder are used to calculate liquid water content. Unlike the rotating multicylinders, however, the cloud droplet size must be known or assumed to compute the collection efficiency of the cylinder which is another input to the liquid water content calculation. A complete description of the single rotating cylinder method is contained in reference 4.

10. The SOOT SLIDE DROPLET SAMPLER (fig. 3(b)), is an electrical solenoid activated droplet sampling device. An inner rod carries a $0.64 \mathrm{~cm}$ ( 0.25 in.) wide plastic sampling slide coated with black soot. The outer $1.59 \mathrm{~cm}(0.63 \mathrm{in.})$ diameter outer tube has a $0.32 \mathrm{~cm}(0.13 \mathrm{in.})$ silt through which the slide is exposed. Upon activation, the solenoid moves the slide behind the open slit, exposing it to the oncoming particles for approximately $6 \mathrm{~ms}$, and then up into the closed upper end of the tube. Droplets impacting the soot slide form craters in the soot. The craters are photographed using a microscope and camera and sized by projecting the negative onto a screen. Particle size is determined from crater size and particle velocity.

11. The ICING BLADE is a LWC measurement method which is only usable at temperatures well below freezing. It has a flat leading edge which is $0.32 \mathrm{~cm}$ ( 0.13 in.) thick, $15.2 \mathrm{~cm}(6 \mathrm{in.})$ long, and $1.91 \mathrm{~cm}(0.75 \mathrm{in.})$ deep. It is exposed to the environment until approximately $0.3 \mathrm{~cm}$ of ice accretes on the leading edge. The exact thickness of ice accreted is measured using a chilled micrometer. The actual ice thickness, the exposure period and true airspeed are used to calculate liquid water content. A more complete description of the blade method is contained in reference 4.

Table I is a listing of each instrument, the manufacturer, serial number and measurement range. Figure 4 shows the location of these instruments on the aircraft. The Leigh Ice Detector, PIRAM, Rosemount Ice Detector, J- $\mathrm{H}$, and CSIRO-KING sensors are installed around the nose of the aircraft, forward of the windscreen. The two laser spectrometers are mounted under the left wing, and the rotating cylinders and icing blade are exposed through the hatch in the upper fuselage, in line with the wing flaps. The soot slide droplet sampler projects through the upper fuselage on the left side of the aircraft. 


\section{TEST PROCEDURES \\ Pre-Filght Checkout}

A pre-flight checkout was performed on all instruments prior to each flight. These checks were performed according to the manufacturers' recommendations supplied with the instruments.

In addition to these checks, a portable spray rig apparatus was used to generate a spray cloud for checkout of the J-W liquid water content system and the FSSP and OAP laser probes. A description of this spray rig is given in the appendix. The spray rig air and water pressures and water flow were set and allowed to stabilize. When placed in the spray cloud, the $J-W$ was required to read between 2.6 and $3.0 \mathrm{~g} / \mathrm{m}^{3}$ in order to pass the checkout. A spray $\mathrm{rig}$ is the only practical way to ensure that the $J-W$ sensing head is working properly. This proved to be a very valuable check. During one pre-flight checkout, the $\mathrm{J}-\mathrm{W}$ sensing head was found to be reading low by approximately 50 percent although the sensor appearance was normal. This problem was traced to poor sensor wire solder connections caused by accidental overheating on the ground. A new sensor head gave the correct LWC response in the spray rig.

Pre-flight checks of the FSSP with the spray rig showed only minor varlations in the size distribution due to water temperature. The FSSP was required to show a peak at 8 to $10 \mu \mathrm{m}$, an activity level of approximately 27 percent, and the same distribution shape in order to pass this pre-filght test. No cases of fallure were experienced during the 1982-1983 filight season. It should be noted that this is only a "reference" calibration check - it insures that the FSSP response has not changed. The actual "calibration standard" used was glass beads.

The OAP was also checked with the spray rig. Since the largest droplets generated by the spray rig were measured by the lower size channels of the probe, this test primarily checked that no large number of spurfous counts were generated in the upper size channels.

\section{In-Fiight Instrument Operation}

All instrumentation was turned on prior to take-off. A cut-out switch supplied power to the anti-icing heaters and the J-W sensing wires oniy when the aircraft airspeed exceeded 80 knots.

All data were recorded on a Pertec digital tape recorder through the onboard data acquisition system. The data rate was set at $1.0 \mathrm{sample} / \mathrm{sec}$.

The J-W LWC system was zeroed for clear air conditions (i.e., no liquid water present) and the zero adjustment was changed whenever necessary to account for drift. The FSSP was used in the 2 to $32 \mu \mathrm{m}$ range, (i.e., Range 1). During data acquisition, liquid water content, drop size, air temperature, and aircraft altitude and velocity data were tabulated for later verification of the in-fight tape recorded data. The data flow through the data acquisition system was monitored using the selectable LED readout and the particle spectra display to insure that the data were being recorded.

When the cloud icing conditions appeared to be continuous, the rotating multicylinders or single cylinders were exposed. 


\section{Aircraft Operation}

Each flight was divided into three phases:

(1) Icing cloud data acquisition and aircraft icing

(2) Aircraft performance tests and selective de-icing, and

(3) Icing cloud data acquisition.

During Phase I, the aircraft was maintained at constant velocity and altitude and was allowed to accrete ice. An attempt was made to stay in icing conditions until a specific amount of ice had accreted on the aircraft. This sometimes necessitated turning the aircraft around before exiting the cloud and flying back through it to extend the time in icing.

Phase II consisted of a series of steady state performance measurements from maximum level flight speed to onset of stall buffet during which the aircraft power required was recorded. The tests were repeated, deicing the wings and then the empennage to establish these component contributions to the overall performance 1055. Performance loss was determined by comparing iced versus uniced measurements. This phase is fully explained in reference 5 .

Phase III was similar to Phase I except that the deicing equipment on the aircraft was cycled to minimize ice accretion on the protected surfaces of the aircraft.

Data from Phases I and III were used to perform the instrument comparison contained in this report.

\section{DATA SET DESCRIPTION}

\section{General}

During the 1982-1983 Icing season, 12 icing fights were conducted. A summary of icing conditions encountered is shown in table II. The first five flights, conducted over a three-week period, were required to resolve installation problems, electrical noise problems, and establish adequate operational procedures to acquire good quality data.

of the remaining seven fights, adequate icing cloud conditions were encountered on all but one. These six flights form the basis for the major portion of the instrument comparison analysis.

\section{Data Reduction Technique}

Flight data were reduced using a software package developed by the Computer Services Division at NASA Lewis Research Center. This software handled the loading of data from the digital tape to the NASA LeRC IBM 370 computer, conversions from voltage level to engineering units, calibration corrections, and calculations. The final output was in the form of tabulated or plotted data averaged over a multiple of the recorded data rate. 
Figures 5(a) and (b) show an example of typical flight profile plots generated by the software package, showing afrcraft airspeed and altitude, static air temperature, icing rate, 11quid water content (LWC) and median volume diameter (MVD) droplet size for an entire filight. The three phases of the flight are bracketed on these plots.

The LWC shown is from the J-W and the MVD is from the FSSP. All data, except icing rate, are averaged over $30 \mathrm{sec}$ for flight profile plots. Icing rate data is not averaged.

During this fight, two rotating multicylinder (RMC) and one single rotating cylinder exposures were made. These exposure periods are also shown on the flight profile plots. Figures $6(a)$ and (b) show an expanded version of the plots for RMC exposure number 1. All data, except icing rates and LWC from the Rosemount Ice Detector and PIRAM, are averaged over $10 \mathrm{sec}$. The Rosemount and PIRAM data are shown for each icing cycle. LWC curves for the J-W, Rosemount, PIRAM, and FSSP are shown along with the straight line average LWC from the rotating multicylinder. Note that the measured LWC from the modern instruments generally show the same trends but the actual measured LWC levels differ. The MVD plot shows the calculated FSSP MVD and the resultant RMC MVD. 1

These rotating multi/single cylinder exposures form the basis for the instrument comparison analyses. A total of 13 multicylinder and 7 single cylinder exposures were performed during six flights.

\section{Data Recovery Record}

Data were not recovered from all of the instruments all of the time. Table III summarizes the data recovery rates for each instrument.

It can be seen from the table that three instruments - the Icing Blade, CSIRO-KING LWC, and OAP - supplied no usable data; they could not be included in any instrument comparison. In addition, only four data points were avallable for the LEIGH IDU and only five soot slides have been analyzed to date. This was determined to be insufficient data for any useful comparison. This leaves the following instruments to be compared:

(Manua 1 "OLD"

$\underline{\text { LWC }}$
"MODERN"

(Automatic, On-Line Data)

$$
\text { Rotating Multi/Single Cylinders }
$$

J-W

Rosemount Ice Detector PIRAM

Drop Size (MVD)

Rotating Multicylinders

FSSP

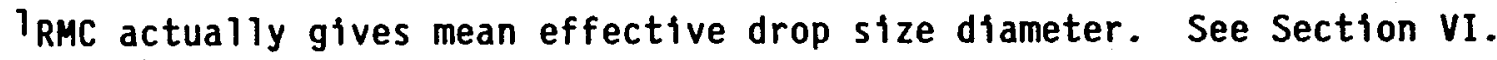




\section{Data Comparison Method}

Two types of instrument comparisons were desired: (1) "01d" versus "Modern" instruments; and (2) "Modern" versus "Modern" instruments. It was decided to use the rotating cylinder exposure periods as the comparison interval for all instrument comparison analysis. Data from all instruments were averaged over the entire exposure time for each rotating cylinder exposure. The maximum and minimum exposure times were 800 and $130 \mathrm{sec}$, respectively, with the average being $433 \mathrm{sec}$.

Averaging all instruments over such a long time period effectively eliminated the differences in frequency response or cycle times between instruments, making the comparison easier. This also tended to reduce the scatter of data, and indicated only the average trends of one instrument versus another.

The icing rate and LWC from the Rosemount Ice Detector and PIRAM are inversely proportional to cycle time (i.e., the higher the LWC, the shorter the icing cycle time). A time-weighted average LWC was calculated for these instruments for each rotating cylinder exposure using the equation:

$$
\overline{L W C}=\frac{\sum\left(L W C_{1} \times t_{1}\right)}{\sum t_{1}}
$$

LWC $_{j}$ LWC from icing cycle $i$

$t_{1}$ ith icing cycle time

Since the data from the J-W and FSSP was continuously sampled at a constant data rate all data was averaged arithmetically.

Scatter plots were then made to compare each "modern" instrument to the rotating cylinder.

\section{RESULTS AND DISCUSSION}

\section{Results of Instrument Comparisons - LWC}

Scatter plots of the instrument data were used to assess the degree of agreement between instruments. A least squares linear regression was performed to generate a best fit line and a correlation coefficient, $r$. For the liquid water content plots, this line was forced through the origin by adding a 0 , 0 data point for each data point pair since all instruments indicated no LWC when in clear air. The standard deviation, $\sigma \mathrm{N}-1$, about the best fit line was computed to assess measurement variability. Two standard deviation limits are shown on the plots; this represents the \pm 95 percent 1 imits for a normal distribution.

Figure $7(a)$ shows a scatter plot of the J-W LWC versus the rotating cylinder LWC. The slope of the least squares line is 1.07 and the correlation coefficient is 0.976 . The standard deviation of the data about this line is 0.047 .

Figure $7(b)$ shows the scatter plot for the Rosemount Ice Detector LWC versus the rotating cylinder LWC. The slope of the least squares line is 0.94 
and the correlation coefficient is 0.919 . The standard deviation of the sample about this line is $0.075,60$ percent greater than the value for the J-W.

Figure $7(\mathrm{c})$ shows the scatter plot for the PIRAM LWC versus the rotating cylinder LWC. The slope of the least squares line is 1.20 and the correlation coefficient is 0.937 . The standard deviation is 0.087 which is slightiy larger than the standard deviation for the Rosemount.

Note that there are two data points from flight 83-11 (RMC LWC $=0.15$, $0.33 \mathrm{~g} / \mathrm{m}^{3}$ ) on all of the comparison plots which consistently show disagreement between the rotating cylinder and the other instruments. This implies that these two rotating cylinder measurements are too low due to loss of fce or other error during the cylinder analysis. In fact, it was noted that some ice may have been lost during weighing of cylinders for the $L W C=0.33 \mathrm{~g} / \mathrm{m}^{3}$ data point. This demonstrates one of the potential errors that can occur when using the rotating cylinder method for determining LWC.

In order to assess the agreement and variability of the "modern" instruments, scatter plots of the Rosemount LWC and PIRAM LWC versus the J-W LWC were generated (figs. $8(a)$ and (b)). In addition to changes in the slopes of the two least square lines, the standard deviations decreased by 32 percent for the Rosemount and 41 percent for the PIRAM. This implies that a substantial amount of the scatter in the comparisons with the rotating cylinder is caused by the scatter in the rotating cylinder data.

\section{Results of Instrument Comparison - Droplet Size}

Figure 9 shows the scatter plot for the FSSP median volume diameter (MVD) droplet size versus the rotating multicylinder MVD. The least squares regression line has a slope of 0.923 , an intercept of 4.07 and a correlation coefficient of 0.776 . The scatter of data is quite large as demonstrated by the standard deviation of 1.39 .

The probable error for the rotating multi cylinder MVD was calculated using an approach to determine errors from reference 3 . The results of this analysis showed that for a RMC indicated value of $15 \mu \mathrm{m}$, the actual MVD could be anywhere between 17.5 and $13 \mu \mathrm{m}$. This only accounted for about 40 percent of the difference shown in the comparison with the FSSP.

The FSSP was also run in the NASA Lewis Icing Research Tunnel (IRT) in an attempt to generate a calibration curve which could be used to correct the probe data. The calibration curve generated from this test indicated that the FSSP reads approximately $5 \mathrm{\mu m}$ high for a MVD range from 10 to $25 \mu \mathrm{m}$. No cal1bration data were generated for MVD $<10 \mu \mathrm{m}$ due to the tunnel imitations. When the IRT-generated curve was applied to the FSSP flight data, the data points shifted down by 4 to $6 \mathrm{\mu m}$. This approach was therefore unsuccessful in explaining the difference between the two instruments.

It should be pointed out that the rotating multicylinder actually measures what is called "mean effective (droplet) diameter" which may differ from the actual median volume diameter. This term is used to account for the fact that the analysis assumes a Langmuir droplet size distribution from which the overall weighted collection efficiency is calculated. If the actual cloud droplet distribution is significantly different from a Langmuir distribution, the mean 
effective diameter will differ from the median volume diameter. Also, the resultant mean effective diameter is the result of the sum of all droplets impinging and freezing on the cylinders during the relatively long period they are exposed. This results in a "LWC-weighted" average droplet size.

The FSSP median volume diameter was computed for each 1 sec sample. These MVD values were then arithmetically averaged to compute the average MVD from the FSSP during each rotating multicylinder exposure. Unifke the rotating multicylinder analysis, this process does not result in a "LWC-weighted" average. Despite the differences in averaging techniques, it is apparent that the FSSP indicates MVD values greater than the rotating multicylinder mean effective diameter. Further testing and analysis of the FSSP and the rotating multicylinder method in flight and in the NASA IRT is planned to further study the causes of this apparent disagreement.

\section{Particle Trajectory Analysis}

NASA Lewis has developed particle trajectory analysis computer codes. One of these codes (ref. 6) was used to examine the relative particle concentrations at the instrument locations. This analysis was performed for the $J-W$, Rosemount Ice Detector, and PIRAM LWC instruments. The anaiys is has not yet been performed for the rotating cylinder, soot slide droplet sampler or laser probe locations.

Although the correction between the local and free-stream LWC is significant, the correction between instrument locations did not significantly effect the aforementioned results.

Further droplet trajectory analysis is planned and will include the rotating cylinder, soot sifde droplet sampler and laser probe locations.

\section{Discussion}

Liquid water content instruments. - In the limited sample of data shown in this analysis the comparison between the J-W and the rotating cylinder data showed excellent agreement, with a slope of 1.07 and scatter in the data of less than $\pm 0.1 \mathrm{gm} / \mathrm{m}^{3}\left(2 \sigma_{\mathrm{n}-1} 1\right.$ imits).

It was shown that the Rosemount IDU data had a slope of less than 1.0 when compared to the $\mathrm{J}-\mathrm{W}$ and rotating cylinders. Part of the reason for this is that the three higher LWC data points were collected at a total temperature of $-4.5^{\circ} \mathrm{C}$. These points are therefore in the Ludlam limit region where a portion of the water striking the sensor does not freeze and runs off the sensor, resulting in a lower LWC reading. This effect is further described in reference 7. An attempt was made to quantify the Ludlam limit effects on this sensor in the NASA Lewis Icing Research Tunnel. However, the Rosemount had insufficient heating capability to de-ice properly below $20^{\circ} \mathrm{F}$ at the liquid water content levels $\left(0.8 \mathrm{~g} / \mathrm{m}^{3}\right)$ of the IRT. This unit is being modified to increase the heating capability and will be rerun in the IRT.

In the PIRAM versus $J-W$ and rotating cylinder data comparisons, the slope was greater than 1.0 and the scatter of data was $\pm 0.17 \mathrm{gm} / \mathrm{m}^{3}\left(2 \sigma_{n+1} 1\right.$ imits $)$. 
Further development and testing of the PIRAM is in progress which should reduce or eliminate these disagreements.

Droplet sizing instruments. - The comparison of the droplet sizing instruments showed that the Forward Scattering Spectrometer Probe (FSSP) indicated an average MVD $3 \mathrm{\mu m}$ higher than the rotating multicylinders. Also, the scatter of data was almost $\pm 3 \mu \mathrm{m}\left(2 \sigma_{n-1} 1\right.$ imits). Much more data are needed to establish a better comparative evaluation between these two techniques since only 17 data samples were available for comparison. In addition, better absolute calibration techniques need to be established for the FSSP. Further testing and ana1ysis is planned to investigate the disagreement between these instruments.

\section{CONCLUSIONS AND RECOMMENDATIONS}

1. Time history plots of LWC showed that the "modern" instruments generally followed the same trends of measured liquid water content (LWC). The measured LWC levels from these instruments differed by varying amounts.

2. The agreement between the Johnson-Williams average LWC and the rotating cylinder LWC was excellent with data scatter of less than $\pm 0.1 \mathrm{gm} / \mathrm{m}^{3}$. The other LWC instruments did not agree as well with the rotating $\overline{c y}$ inder LWC and had 66 to 89 percent more scatter.

3. The comparison of droplet sizing instruments showed substantial disagreement ( $3 \mu \mathrm{m}$ MVD) between the rotating multicylinder and the laser spectrometer, and considerable data scatter (approximately 5.5 um MVD).

4. Additional comparative data are needed for all instruments to increase the statistical confidence of the results presented.

5. Additional particle trajectory analyses are needed to define the local droplet concentrations for all instrument locations and to define the relative droplet size concentrations at the rotating multicylinder, soot slide sampler and laser spectrometer locations. These analyses will allow comparisons to be made on a more uniform basis.

6. Based on the results of this flight investigation, icing wind tunnel testing is necessary to evaluate instrument performance characteristics with respect to velocity, temperature, liquid water content and droplet size.

7. Comprehensive pre-flight checkout procedures need to be performed if high quality data is to be gathered. A portable spray rig is extremely useful for checkout of hot-wire LWC instruments and laser spectrometers. 


\section{APPENDIX}

\section{PORTABLE SPRAY RIG}

The portable spray rig apparatus utilized for pre-flight checkout of the J-W liquid water meter and the laser spectrometer probes consists of two separate components, connected by flexible flow and power lines. (See fig. 10). One component consists of a portable stand containing a storage tank of demineralized water; an air system utilizing 125 psig service air, which supplies controlled air to a water spray nozzle and pressurizes the water storage tank; a water flow control system for supplying water to the spray nozzle; and a variable power supply for operation of a blower on the "spray cloud generator" component. The "spray cloud generator" consists of a variable speed blower mounted on a converging nozzle; a removable spray nozzle tube; a water spray nozzle with close-coupled pressure gages for monitoring air and water pressures; and a thermocouple for monitoring water temperature at the nozzle. These two components are interconnected by flexible Tygon tubing for the air and water, and a flexible power cord for the blower. The "spray cloud generator" is mounted on a telescoping stand which allows for positioning the generator in front of the various instruments mounted on the Twin otter aircraft wing and nose. It is positioned by means of an appropriate fixture which maintains proper alignment and distance for repeatable operation. 


\section{REFERENCES}

1. 0lsen, W., "Survey of Aircraft Icing Simulation Test Facilities in North America," NASA TM-81707, Feb. 1981.

2. 01sen,W., Takeuch1, D., Adams, K., "Experimental Comparison of Icing Cloud Instruments," NASA TM-83340, Jan. 1983.

3. Brun, R. J., Lewis, W., Perkins, P. J., Serafini, J. S., "Impingement of Cloud Droplets on a Cylinder and Procedure for Measuring Liquid-Water Content and Droplet Sizes in Super Cooled Clouds by Rotating Multicylinder Method," NACA Rep. 1215, 1955, pp. 141-184.

4. Stallabrass, J. R., "An Appraisal of the Single Rotating Cylinder Method of Liquid Water Content Measurement," NRC-Canada LTR-LT-92, Nov. 1978.

5. Ranaudo, R. J., McKnight, R. C., Mikkelsen, K. C., Perkins, P. J., "Performance Degradation of a Typical Twin Engine Commuter Type Aircraft in Measured Natural Icing Conditions," AIAA Paper 84-0179, Jan. 1984.

6. Norment, H. G., "Calculation of Water Drop Trajectories to and about Arbitrary Three-Dimensional Bodies in Potential Airflow, "NASA CR-3291, 1980.

7. Brown, E. N., "Ice Detector Evaluation for Aircraft Hazard Warning and Undercooled Water Content Measurements," AIAA Paper 82-4273, Nov. 1982. 
TABLE I. - LIST OF ICING INSTRUMENTS

\begin{tabular}{|c|c|c|c|c|c|}
\hline Instrument Name & Mode 1 & $\begin{array}{l}\text { Serial } \\
\text { number }\end{array}$ & Manufacturer & Instrument type & $\begin{array}{l}\text { Approximate } \\
\text { range }\end{array}$ \\
\hline $\begin{array}{l}\text { J-W Liquid Water Content } \\
\text { Meter }\end{array}$ & LWH-1 & CT-20 & $\begin{array}{l}\text { Cloud Technology, } \\
\text { Inc. }\end{array}$ & LWC: hot wire type & $0-2,0-6 \mathrm{~g} / \mathrm{m}^{3}$ \\
\hline Rosemount Ice Detector & $871 F A$ & 496 & Rosemount, Inc. & $\begin{array}{l}\text { LWC ICING RATE: } \\
\text { ice accretion type }\end{array}$ & $0.15-3 \mathrm{~g} / \mathrm{m}^{3}$ \\
\hline $\begin{array}{l}\text { Pressure Ice Rate and } \\
\text { Accretion Meter }\end{array}$ & ----- & ----- & NASA & $\begin{array}{l}\text { LWC \& ICING RATE: } \\
\text { ice accretion type }\end{array}$ & $0.15-3 \mathrm{~g} / \mathrm{m}^{3}$ \\
\hline Leigh Ice Detector & MK-12A & 23 & $\begin{array}{l}\text { Leigh Instruments } \\
\text { Limited }\end{array}$ & $\begin{array}{l}\text { LWC: ice accretion } \\
\text { type }\end{array}$ & $0-2 \mathrm{~g} / \mathrm{m}^{3}$ \\
\hline $\begin{array}{l}\text { CSIRO-King Liquid Water } \\
\text { Content Meter }\end{array}$ & ------ & $0582-06$ & $\begin{array}{l}\text { Particle Measuring } \\
\text { Systems, Inc. }\end{array}$ & LWC: hot wire type & $0-1,0-3 \mathrm{~g} / \mathrm{m}^{3}$ \\
\hline $\begin{array}{l}\text { Forward Scattering Spect- } \\
\text { rometer Probe }\end{array}$ & FSSP -100 & $0382-75$ & $\begin{array}{l}\text { Particle Measuring } \\
\text { Systems, Inc. }\end{array}$ & $\begin{array}{l}\text { DROPLET SIZING: } \\
\text { laser light scatter- } \\
\text { ing }\end{array}$ & $\begin{array}{l}0.5-47 \mu \mathrm{m} \\
(4 \text { ranges })\end{array}$ \\
\hline Optical Array Probe & $0 A P-200 x$ & $0382-27$ & $\begin{array}{l}\text { Particle Measuring } \\
\text { Systems, Inc. }\end{array}$ & $\begin{array}{l}\text { DROPLET SIZING: } \\
\text { laser light shadow- } \\
\text { ing }\end{array}$ & $20-300 \mu \mathrm{m}$ \\
\hline Rotating Multicylinders & ------- & ------- & NASA & $\begin{array}{l}\text { LWC \&DROPLET SIZING: } \\
\text { ice accretion type } \\
\text { (manual data reduct- } \\
\text { ion) }\end{array}$ & $\begin{array}{l}0.1-3.0 \mathrm{~g} / \mathrm{m}^{3} \\
5-30 \mu \mathrm{m}\end{array}$ \\
\hline Single Rotating Cylinder & ------ & ------- & NASA & $\begin{array}{l}\text { LWC: ice accretion } \\
\text { type (manual data } \\
\text { reduction) }\end{array}$ & $0.1-3.0 \mathrm{~g} / \mathrm{m}^{3}$ \\
\hline $\begin{array}{l}\text { Soot Slide Droplet Samp- } \\
\text { ler }\end{array}$ & ------ & ------- & NASA & $\begin{array}{l}\text { DROPLET SIZING: } \\
\text { impactor type(manual } \\
\text { data reduct ion) }\end{array}$ & $2-200 \mu \mathrm{m}$ \\
\hline Icing Blade & ------ & ------- & NASA & $\begin{array}{l}\text { LWC: ice accretion } \\
\text { type (manual data } \\
\text { reduction) }\end{array}$ & -----_--- \\
\hline
\end{tabular}


TABLE II . - 1982-83 FLIGHT SUMMARY

\begin{tabular}{|c|c|c|c|c|c|c|c|}
\hline $\begin{array}{l}\text { Research } \\
\text { flight }\end{array}$ & Date & Encounter & $\begin{array}{l}\text { TAS, } \\
\text { knots }\end{array}$ & $\begin{array}{c}\text { Altitude, } \\
\text { ft }\end{array}$ & Static temp., & $\begin{array}{l}\mathrm{LWC} \\
\mathrm{g} / \mathrm{m}^{3}\end{array}$ & $\operatorname{MVO}_{\mu \mathrm{m}}$ \\
\hline $83-01$ & $1 / 24 / 83$ & $\begin{array}{l}1 \\
2\end{array}$ & $\begin{array}{l}\sim 150 \\
142.0\end{array}$ & $\begin{array}{l}7000 \\
7000\end{array}$ & $\begin{array}{l}-10.1 \\
-11.5\end{array}$ & $\begin{array}{r}\sim .55 \\
.48\end{array}$ & $\begin{array}{l}\sim 12.5 \\
\sim 13.0\end{array}$ \\
\hline $83-02$ & $1 / 31 / 83$ & $\begin{array}{l}1 \\
2 \\
3\end{array}$ & $\begin{array}{l}124.4 \\
126.0 \\
129.0\end{array}$ & $\begin{array}{l}4900 \\
4900 \\
3850\end{array}$ & $\begin{array}{r}-9.8 \\
-8.4 \\
\sim-7.8\end{array}$ & $\begin{array}{r}.29 \\
.55 \\
\sim .12\end{array}$ & $\begin{array}{l}12.5 \\
10.5 \\
\text { N.A. }\end{array}$ \\
\hline $83-03$ & $2 / 3 / 83$ & $\begin{array}{l}1 \\
2 \\
3\end{array}$ & $\begin{array}{l}143.2 \\
143.2 \\
147.4\end{array}$ & $\begin{array}{l}5500 \\
5500 \\
5600\end{array}$ & $\begin{array}{l}-9.9 \\
-9.2 \\
-8.1\end{array}$ & $\begin{array}{l}.27 \\
.15 \\
.21\end{array}$ & $\begin{array}{r}11.8 \\
8.8 \\
6.6\end{array}$ \\
\hline $83-04$ & $2 / 16 / 83$ & \multicolumn{6}{|c|}{ INSUFF ICIENT DATA OBTAINED } \\
\hline $83-05$ & $2 / 17 / 83$ & $\begin{array}{l}1 \\
\mathrm{~b}_{2} \\
3 \\
4\end{array}$ & $\begin{array}{l}145.1 \\
160 \rightarrow 125 \\
\sim 140 \\
145.0\end{array}$ & $\begin{array}{c}7000 \\
7700 \rightarrow 2700 \\
\sim 5000 \\
6000\end{array}$ & $\begin{array}{l}-7.7 \\
-10 \rightarrow-2 \\
\sim-6 \\
-6.5\end{array}$ & $\begin{aligned} & .27 \\
& \sim .15 \\
& \sim .2 \\
& .37\end{aligned}$ & $\begin{array}{r}14.7 \\
\sim 12.0 \\
\sim 10.0 \\
16.7\end{array}$ \\
\hline $83-06$ & $2 / 25 / 83$ & 1 & 134.4 & 4100 & -9.5 & .15 & 9.6 \\
\hline $83-07$ & $3 / 9 / 83$ & $\begin{array}{l}c_{1} \\
2 \\
3 \\
4\end{array}$ & $\begin{array}{l}120 \rightarrow 150 \\
145.3 \\
144.5 \\
147.0\end{array}$ & $\begin{array}{c}\stackrel{2500 \rightarrow 9000}{ } \rightarrow 000 \\
8100 \\
7200\end{array}$ & $\begin{array}{l}+1 \rightarrow-5 \\
-7.5 \\
-8.8 \\
-6.6\end{array}$ & $\begin{array}{l}\sim .2 \\
.11 \\
.20 \\
.08\end{array}$ & $\begin{array}{l}\sim 21 \\
\sim 20 \\
\text { N.A. } \\
\text { N.A. }\end{array}$ \\
\hline $83-08$ & $3 / 10 / 83$ & $\begin{array}{l}1 \\
2 \\
3\end{array}$ & $\begin{array}{r}\sim 137 \\
147.0 \\
146.0\end{array}$ & $\begin{array}{r}\sim 5100 \\
8200 \\
7200\end{array}$ & $\begin{aligned} \sim & -4 \\
& -6.7 \\
& -6.0\end{aligned}$ & $\begin{array}{r}\sim .15 \\
.14 \\
.10\end{array}$ & $\begin{array}{l}\sim 15 \\
17.8 \\
18.0\end{array}$ \\
\hline $83-09$ & $3 / 11 / 83$ & $\begin{array}{l}1 \\
2 \\
3\end{array}$ & $\begin{array}{l}115.3 \\
135.2 \\
128.0\end{array}$ & $\begin{array}{l}4000 \\
4100 \\
3600\end{array}$ & $\begin{array}{l}-7.7 \\
-6.9 \\
-6.8\end{array}$ & $\begin{array}{l}.71 \\
.45 \\
.60\end{array}$ & $\begin{array}{l}14.7 \\
\sim 20 \\
16.4\end{array}$ \\
\hline $83-10$ & $3 / 21 / 83$ & $\begin{array}{l}1 \\
2 \\
3\end{array}$ & $\begin{array}{l}136.7 \\
143.8 \\
\sim 136\end{array}$ & $\begin{array}{r}4200 \\
5500 \\
\sim 3500\end{array}$ & $\begin{aligned} &-5.0 \\
&-7.3 \\
&-6.3 \rightarrow 4.7\end{aligned}$ & $\begin{aligned} & .28 \\
& .21 \\
& \sim .65\end{aligned}$ & $\begin{array}{r}19.7 \\
20.9 \\
\sim 15\end{array}$ \\
\hline $83-11$ & $3 / 21 / 83$ & $\begin{array}{l}c_{1} \\
2 \\
3\end{array}$ & $\begin{array}{l}107 \rightarrow 1-20 \\
139.5 \\
-144\end{array}$ & $\begin{array}{c}2800 \rightarrow 10000 \\
5500 \\
\sim 5400\end{array}$ & $\begin{array}{l}-5 \rightarrow-9 \\
-11.5 \\
-12\end{array}$ & $\begin{array}{l}\sim .5 \rightarrow .15 \\
.2-.6 \\
.3-.8\end{array}$ & $\begin{array}{l}\sim 16 \\
18.2 \\
\sim 15\end{array}$ \\
\hline $83-12$ & $3 / 22 / 83$ & 1 & -141 & $\sim 6000$ & -15 & $.05-.4$ & $\sim 10$ \\
\hline
\end{tabular}

aEstimated average values from all available data

bIcing encountered during altitude change

$\mathrm{C}$ Icing encountered during $\mathrm{climb-out}$

N.A. - Not acquired 
TABLE III. - DATA RECOVERY SUMMARY

\begin{tabular}{|c|c|c|c|}
\hline Instrument & $\begin{array}{l}\text { Usable datapoints/ } \\
\text { total datapoints }\end{array}$ & $\begin{array}{l}\text { Percent } \\
\text { recovery, } \\
\text { percent }\end{array}$ & Comments \\
\hline $\begin{array}{l}\text { J-W Liquid Water } \\
\text { Content Meter }\end{array}$ & $20 / 20$ & 100 & \\
\hline Rosemount Ice Detector & $20 / 20$ & 100 & \\
\hline $\begin{array}{l}\text { Pressure Ice Rate } \\
\text { and Accretion Meter }\end{array}$ & $20 / 20$ & 100 & \\
\hline Leigh Ice Detector & $4 / 20$ & 25 & $\begin{array}{l}\text { Bleed air pressure too low; } \\
\text { data acquisition channel } \\
\text { failure }\end{array}$ \\
\hline $\begin{array}{l}\text { CSIRO-King Liquid Water } \\
\text { Content Meter }\end{array}$ & --- & 0 & $\begin{array}{l}\text { No inflight operation due } \\
\text { to operation and calibration } \\
\text { problems }\end{array}$ \\
\hline $\begin{array}{l}\text { Forward Scattering } \\
\text { Spectrometer Probe }\end{array}$ & $11 / 20$ & 55 & $\begin{array}{l}\text { Probe malfunctions caused by } \\
\text { icing of sample tube }\end{array}$ \\
\hline Optical Array Probe & $0 / 20$ & 0 & $\begin{array}{l}\text { Cloud droplets below usable } \\
\text { range of probe }\end{array}$ \\
\hline Rotating Cylinders & $20 / 20$ & 100 & \\
\hline $\begin{array}{l}\text { Soot Slide Droplet } \\
\text { Sampler }\end{array}$ & $5 / 60$ & 8 & $\begin{array}{l}\text { Only } 5 \text { samples analyzed due } \\
\text { to extensive time required }\end{array}$ \\
\hline Icing B Tade & $0 / 2$ & 0 & $\begin{array}{l}\text { Air temperature too high for } \\
\text { proper use of instrument }\end{array}$ \\
\hline
\end{tabular}




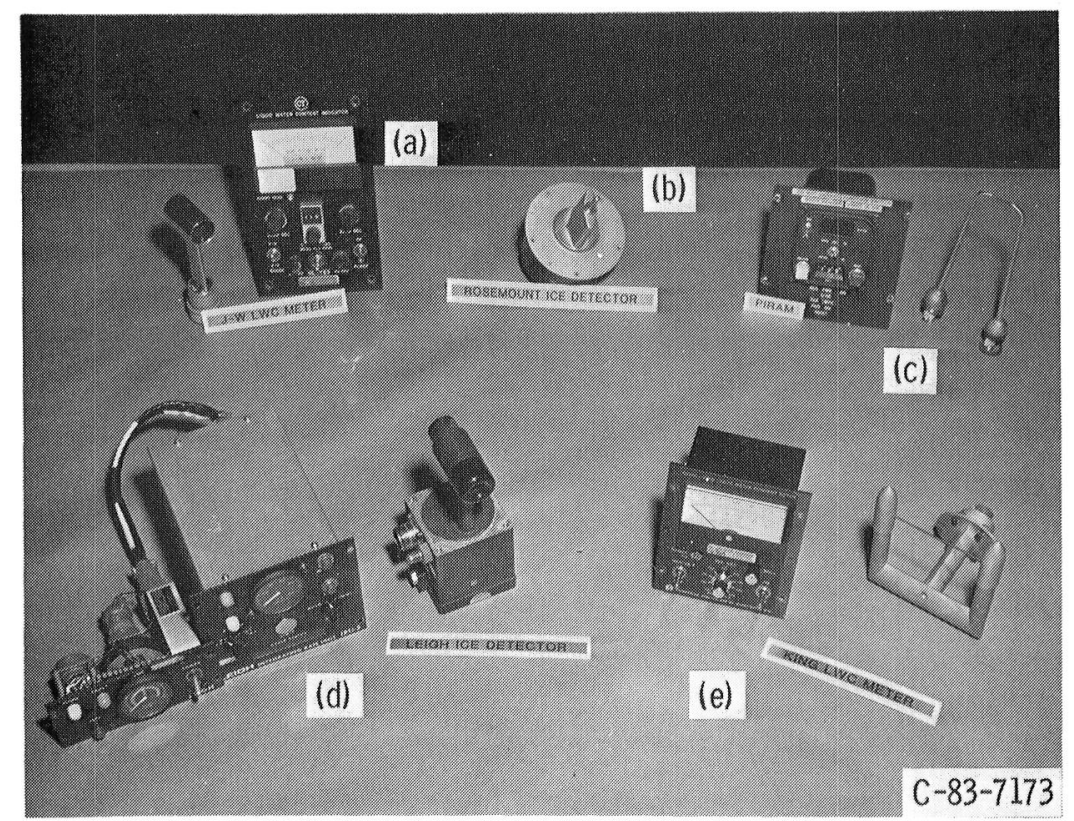

Figure 1. - Liquid water content instruments (a) Johnson-Williams, (b) Rosemount ice detector, (c) pressure ice rate and accretion meter, (d) Leigh ice detector, (e) CSIRO-KING.

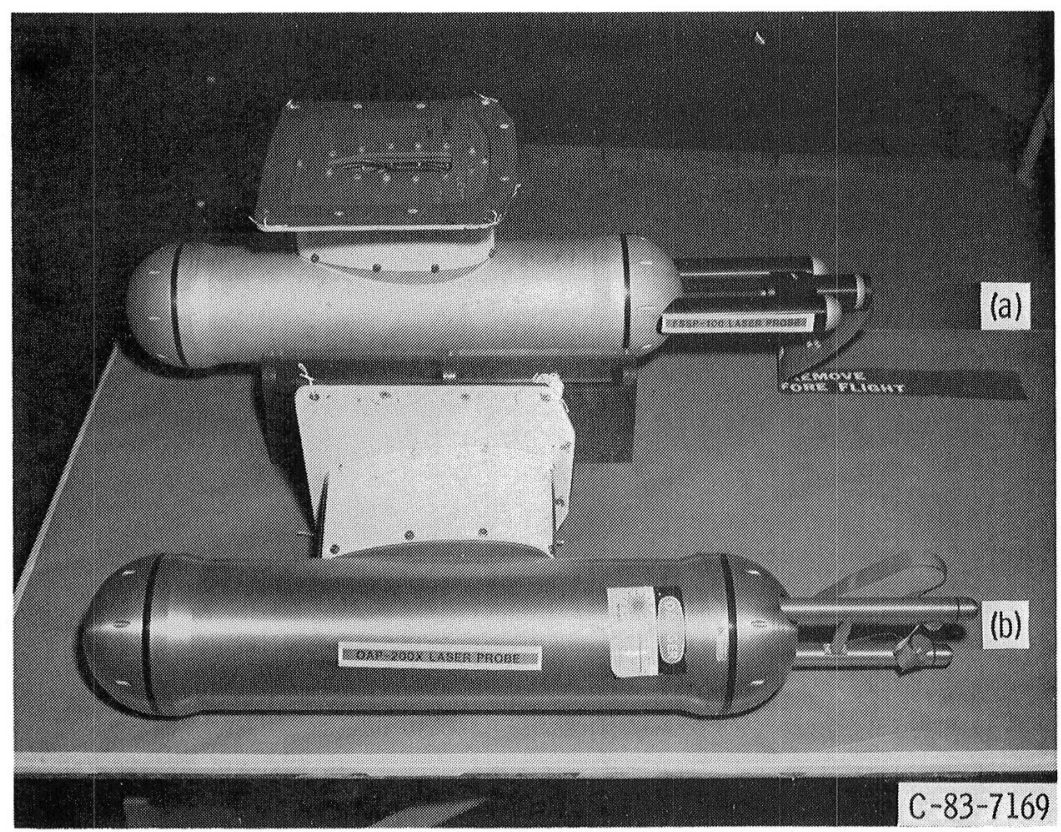

Figure 2. - Droplet sizing instruments (a) forward scattering spectrometer probe, (b) optical array probe. 


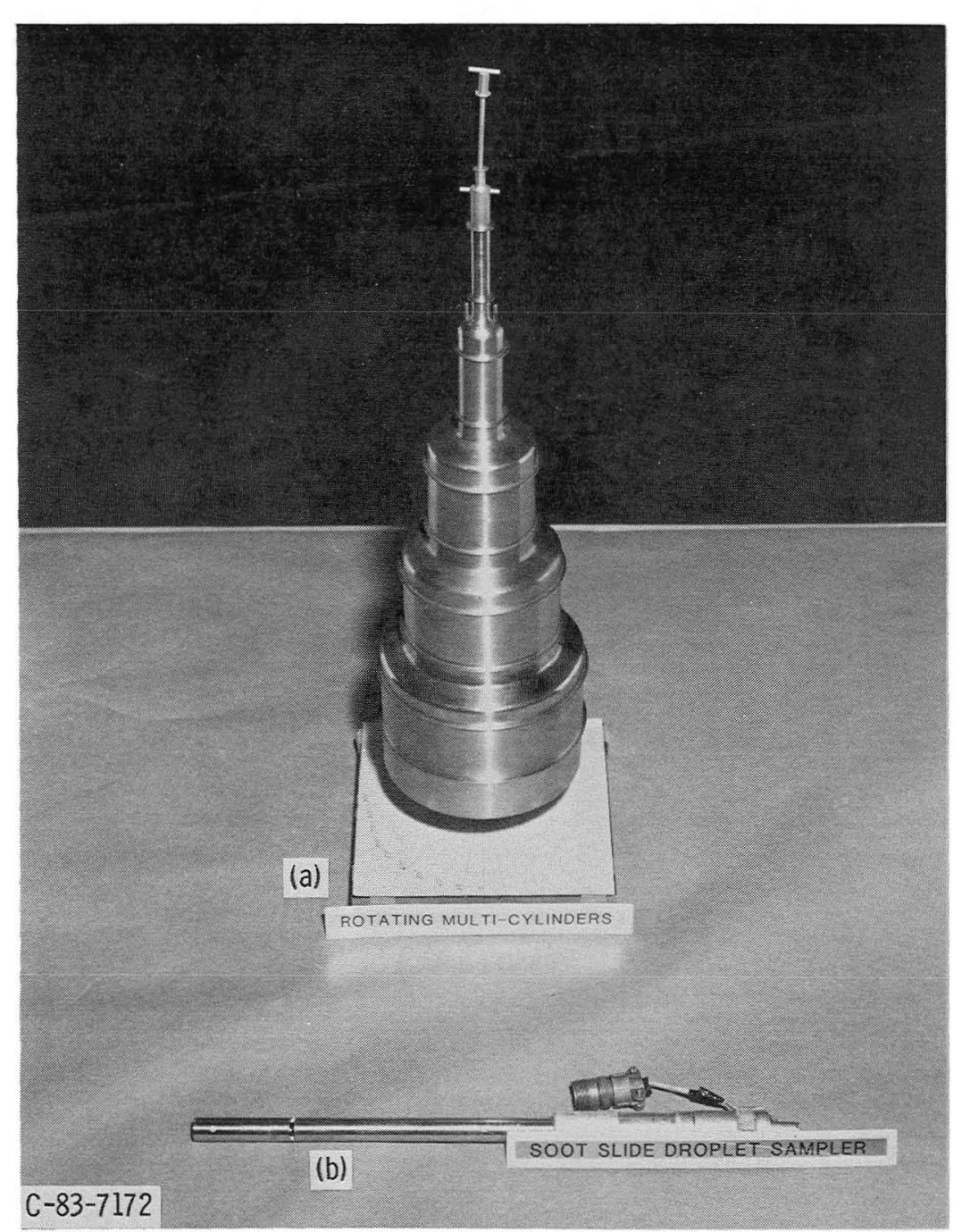

Figure 3. - Old style instruments (a) rotating multicylinders, (b) soot slide droplet sampler.

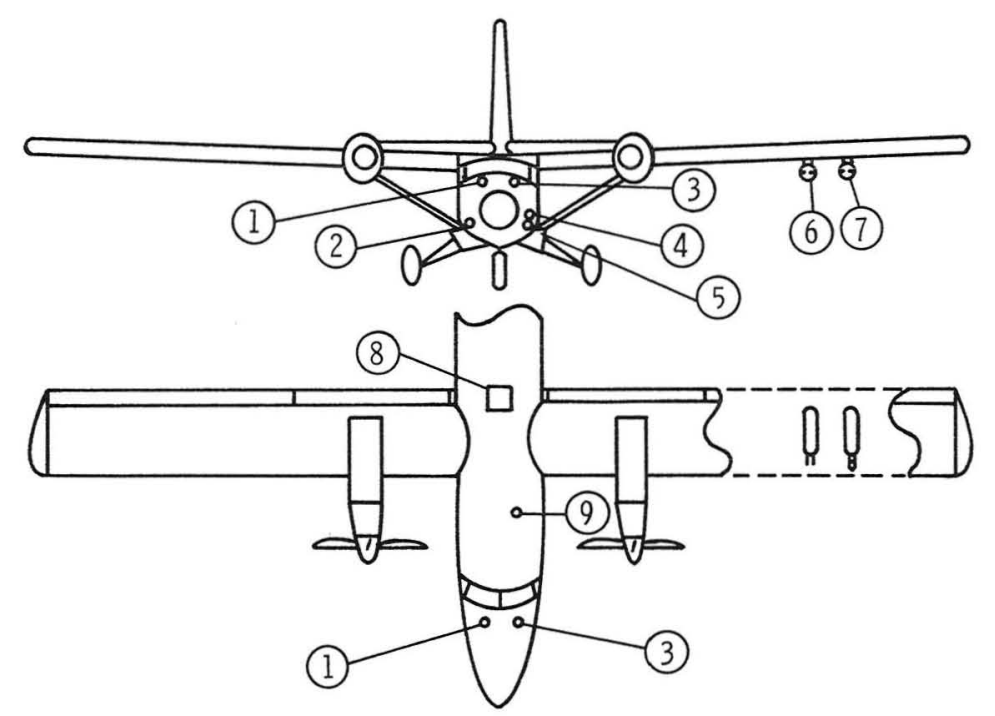

1. LEIGH ICE DETECTOR

2. PRESSURE ICE RATE AND ACCRETION SENSOR

3. ROSEMOUNT ICE DETECTOR

4. J-W LIQUID WATER CONTENT SENSOR

5. CSIRO-KING LIQUID WATER CONTENT SENSOR

6. OAP LASER SPECTROMETER

7. FSSP LASER SPECTROMETER

8. EXPERIMENT CARRIER PORT (ROTATING CYLINDERS AND ICING BLADE)

9. SOOT SLIDE DROPLET SAMPLER

Figure 4. - Icing instrument locations on NASA 508 TWIN OTTER. 

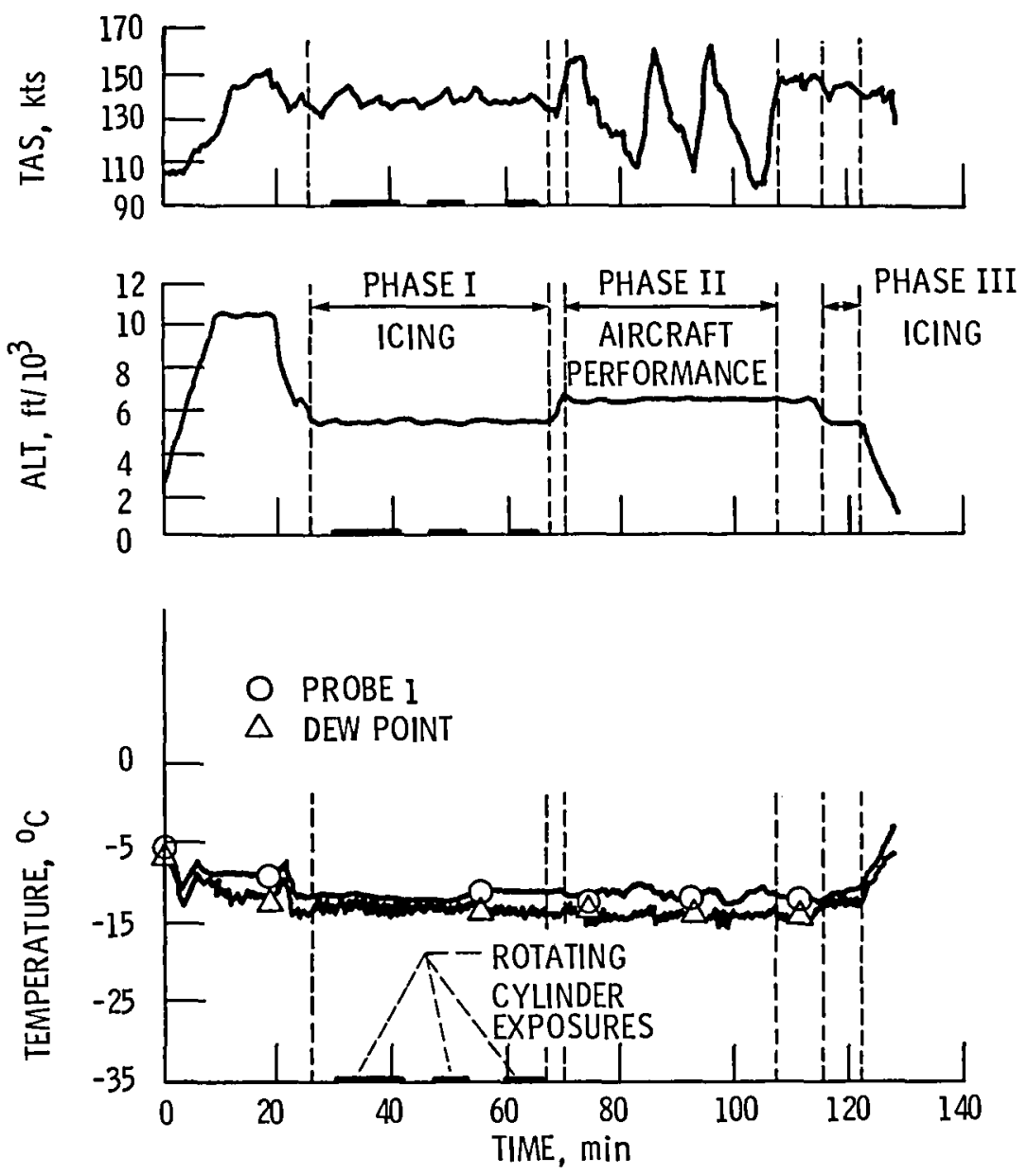

(a) True airspeed, altitude, and static air temperature and dew point.

Figure 5. - Flight profile plots from flight 83-11.
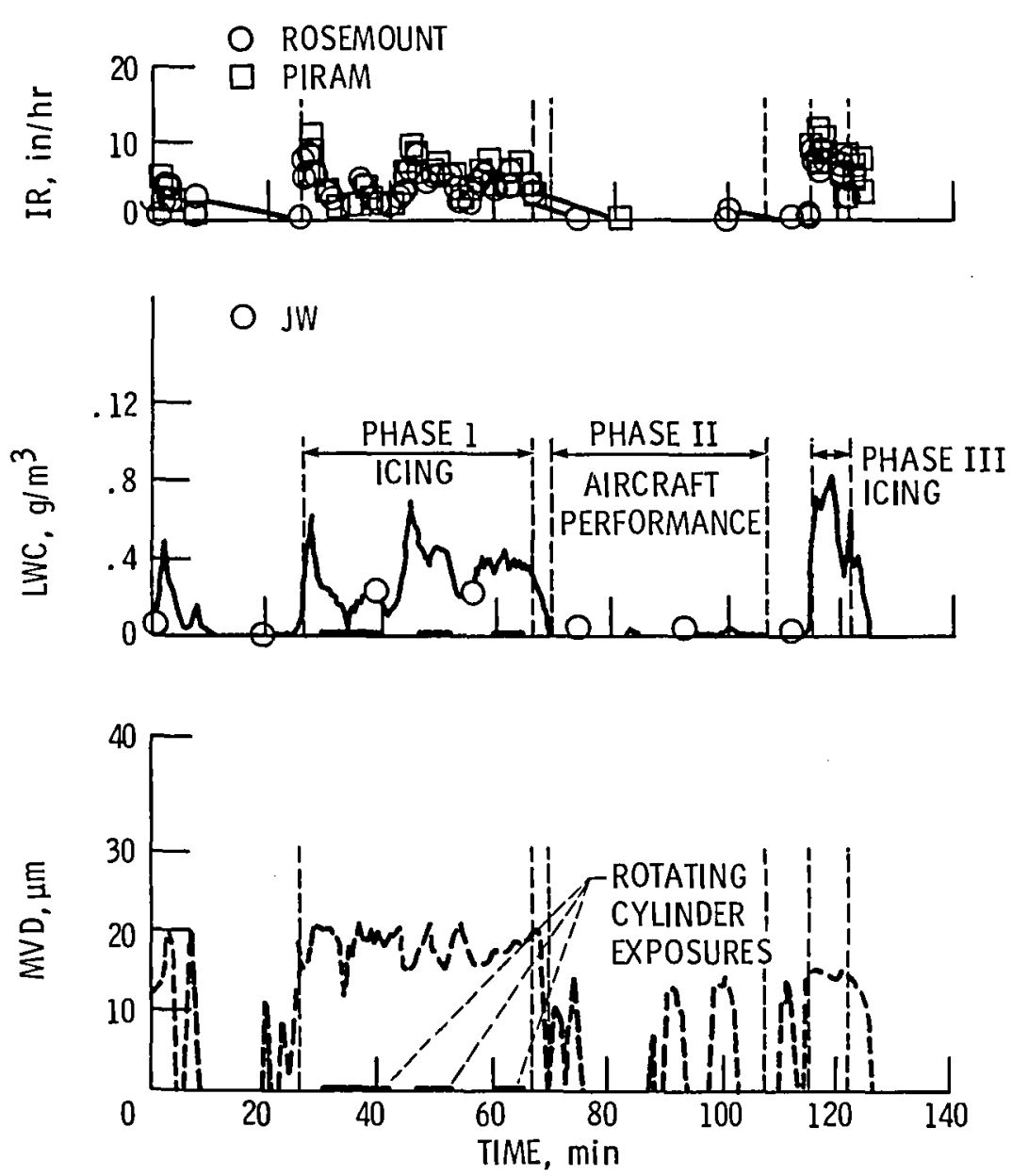

(b) Icing rate, liquid water content, and median volume diameter droplet size.

Figure 5. - Concluded. 

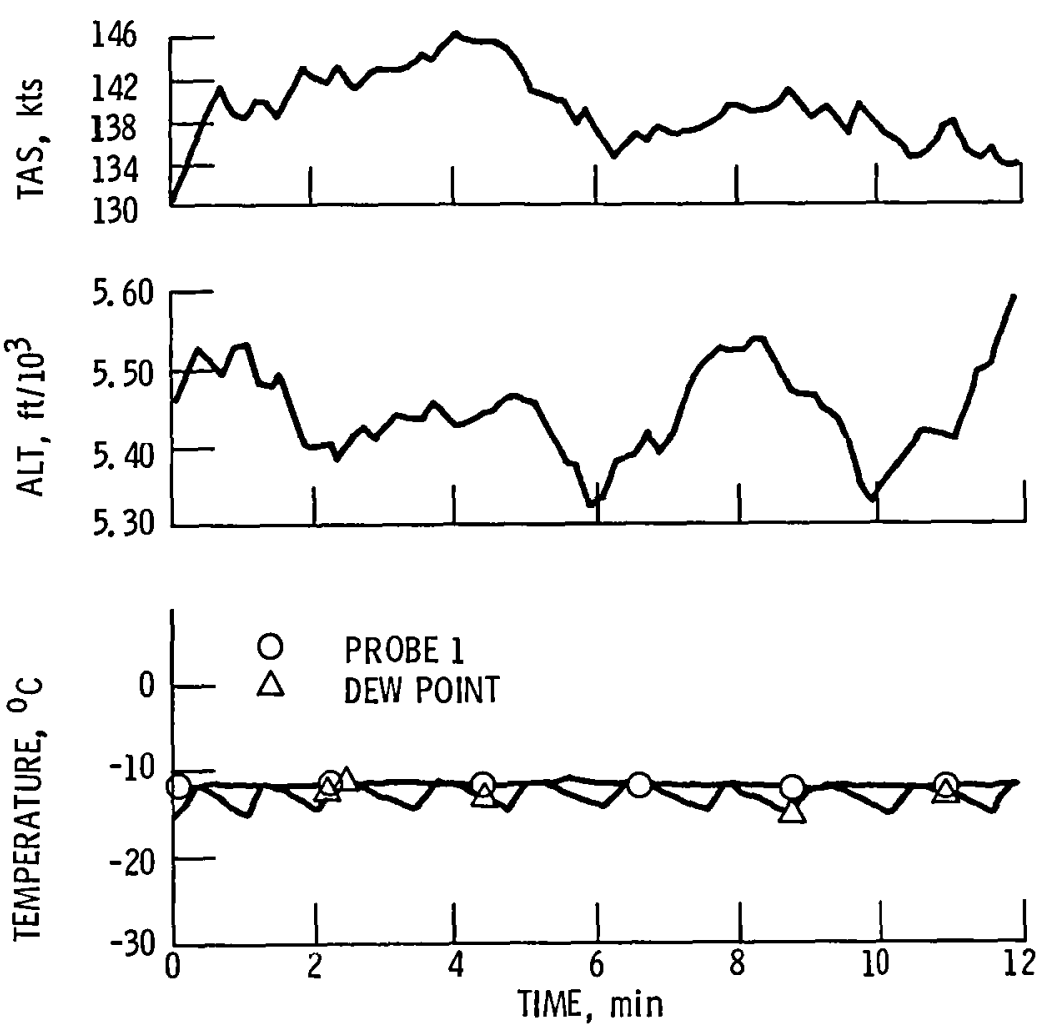

(a) True airspeed, altitude, and static air temperature and dew point.

Figure 6. - Data plots for rotating multicylinder exposure \#1.
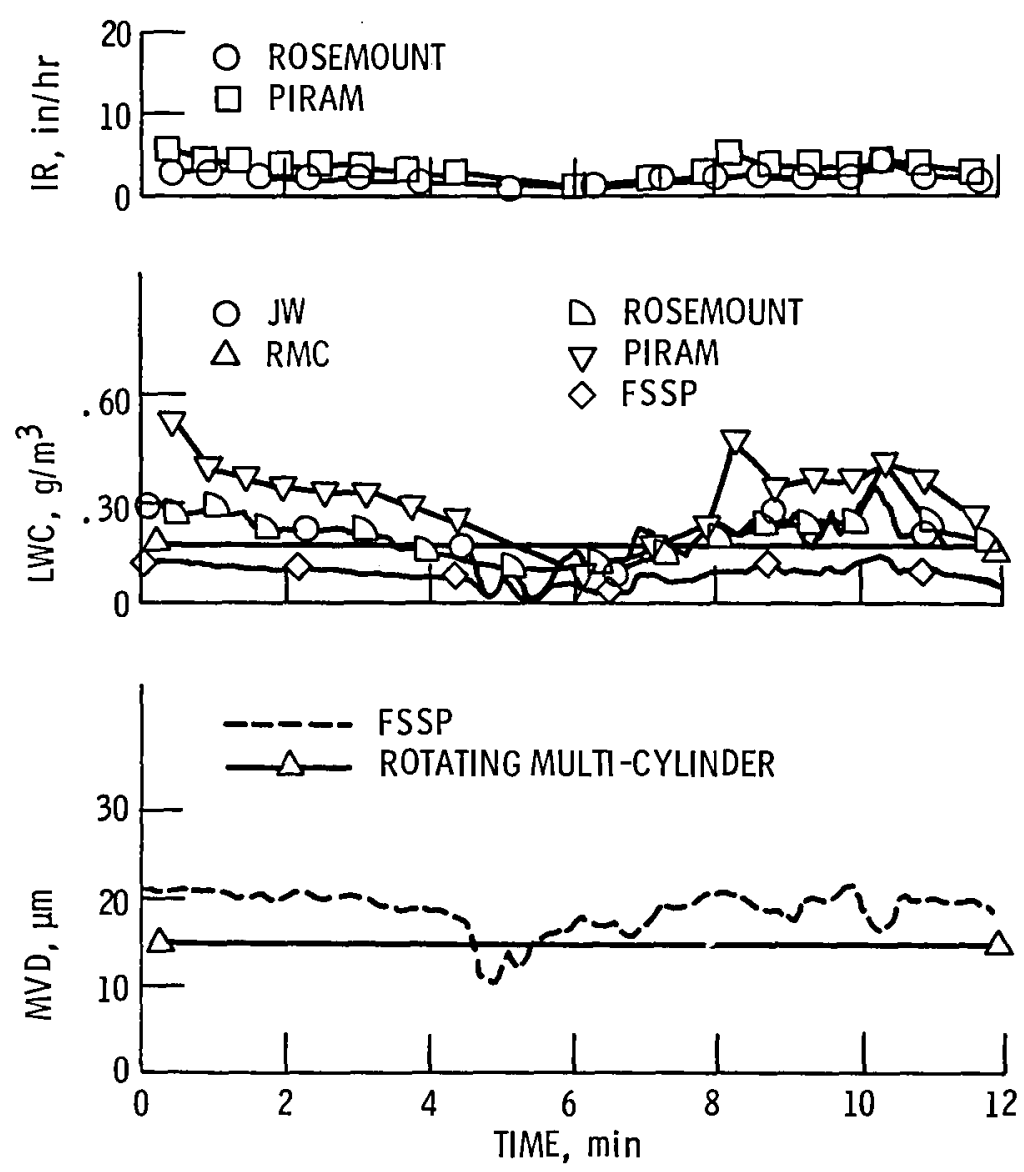

(b) Icing rate, liquid water content, and median volume diameter droplet size.

Figure 6. - Concluded. 

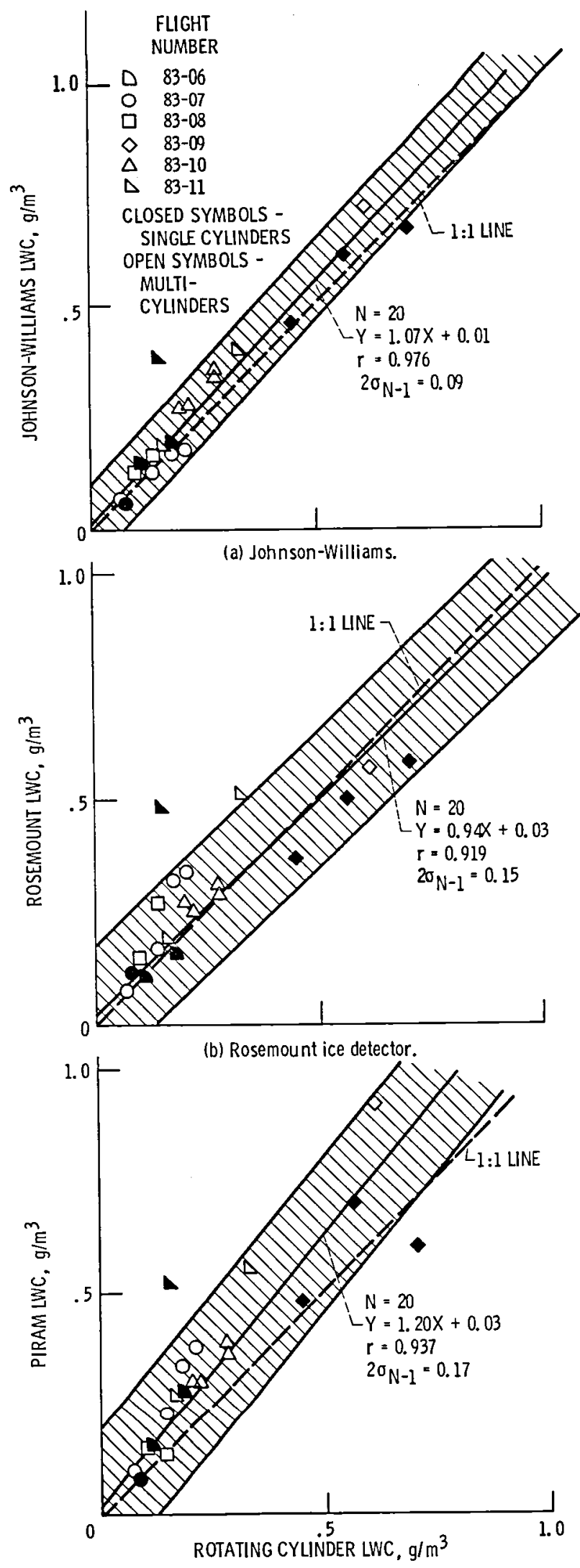

(c) Pressure ice rate and accretion meter.

Figure 7. - Comparison of the "modern" liquid water content instruments to the rotating cylinder. 


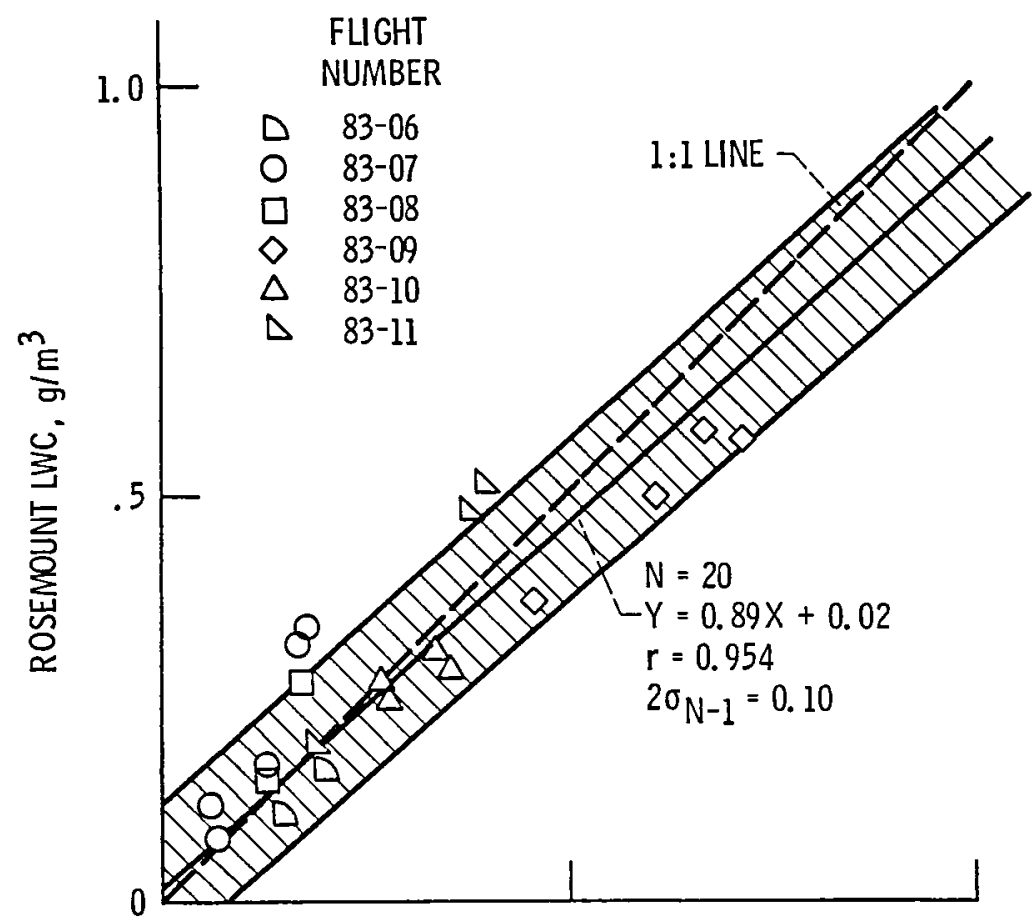

(a) Rosemount ice detector.

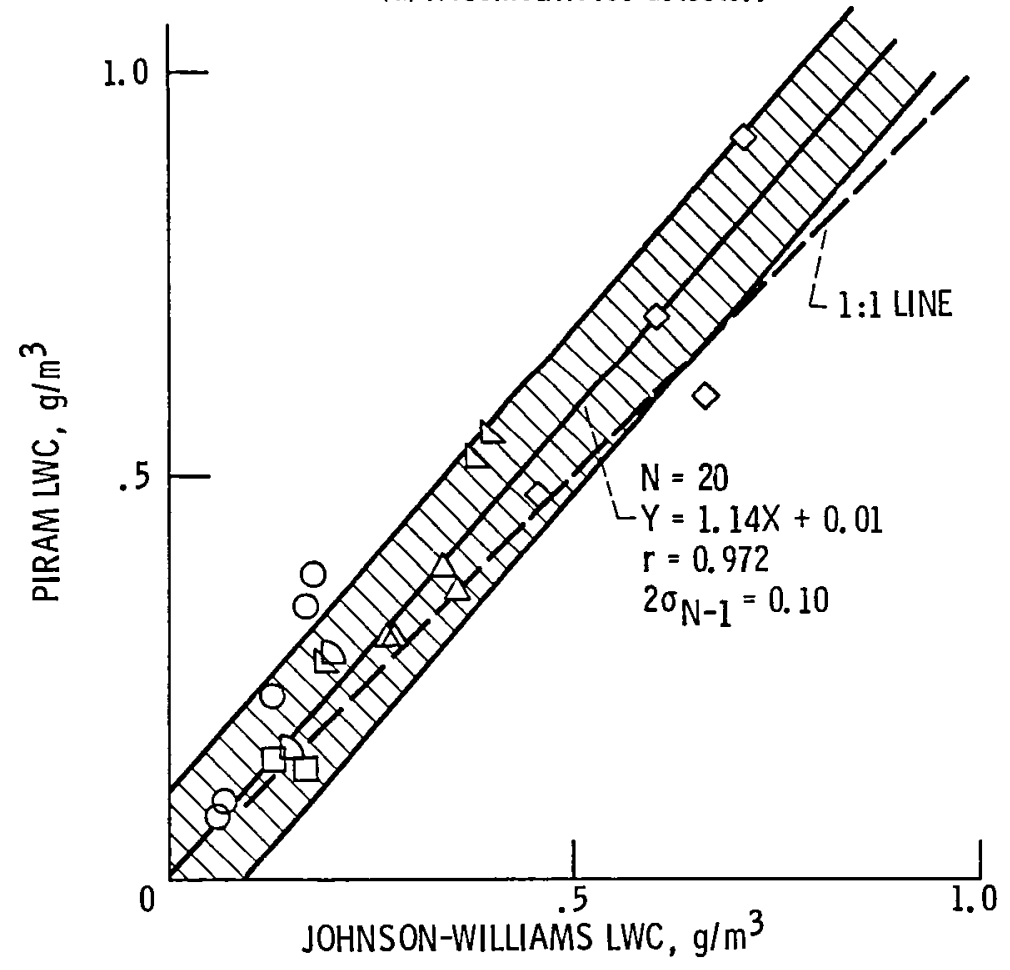

(b) Pressure ice rate and accretion meter.

Figure 8. - Comparison of LWC instruments to the Johnson-Williams LWC. 


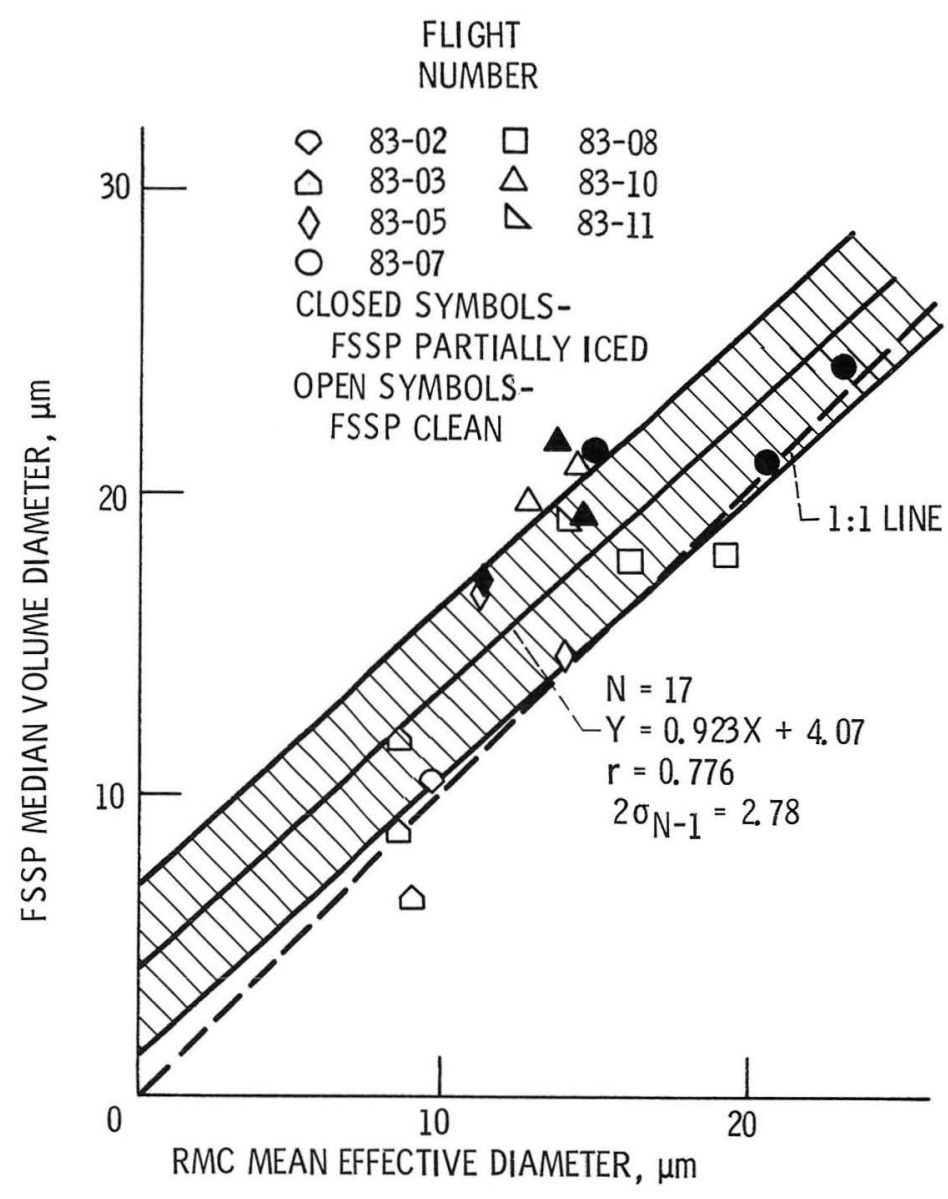

Figure 9. - Comparison of the FSSP median volume diameter to the rotating multicylinder.

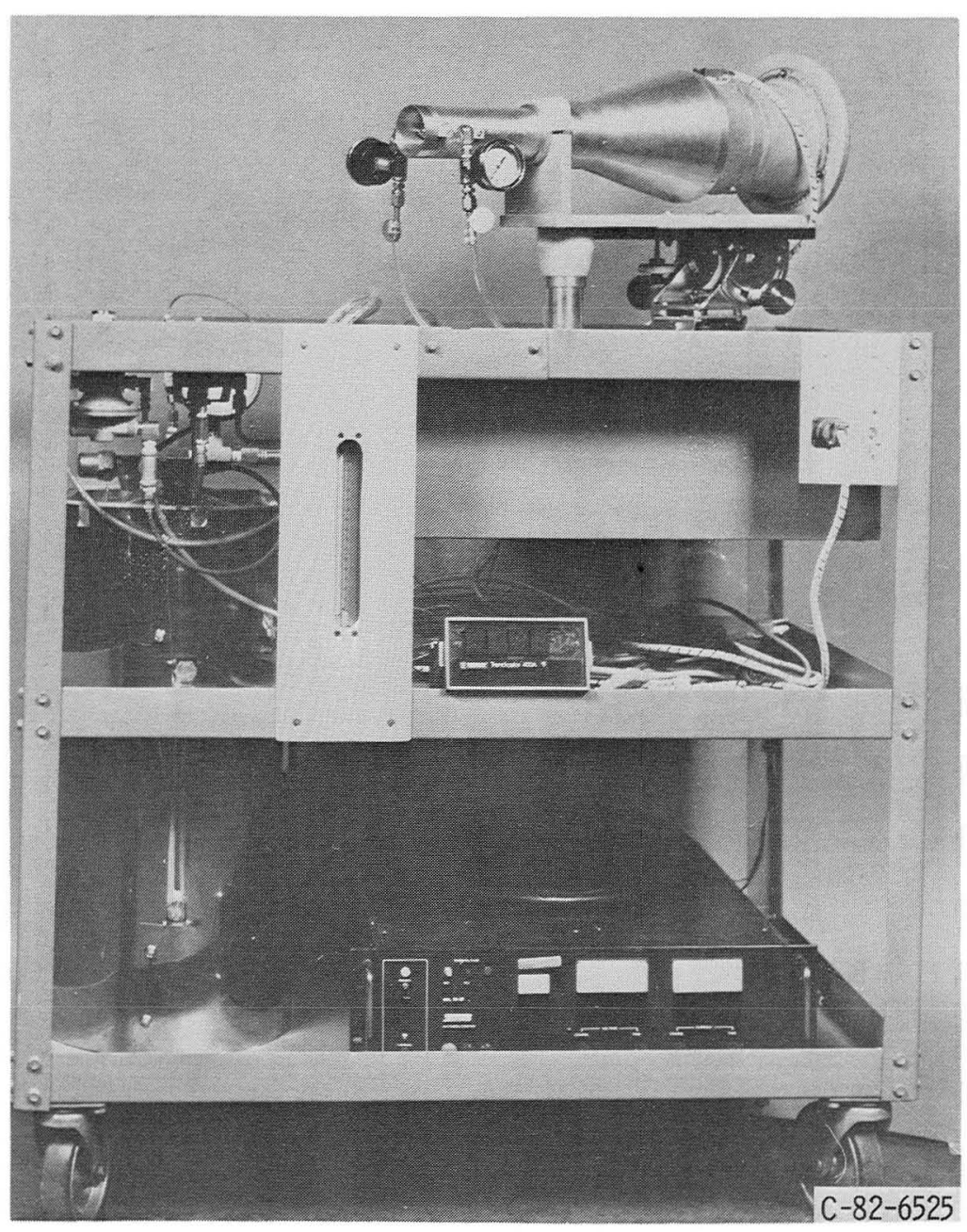

Figure 10. - Portable spray rig used for pre-flight instrument check-outs。 


\begin{tabular}{|c|c|}
\hline $\begin{array}{l}\text { 1. Repor No. NASA TM- } 83569 \\
\text { USAAVSCOM-TR-84-C-1 }\end{array}$ & 3. Recipient's Catalog tos. \\
\hline \multirow{3}{*}{$\begin{array}{l}\text { 4. Title and Subtitle } \\
\text { Comparison of Icing Cloud Instruments for 1982-1983 } \\
\text { Icing Season Flight Program }\end{array}$} & 5. Report Date \\
\hline & \\
\hline & $\begin{array}{l}\text { 6. Pertorming Organization Code } \\
505-45-1 A\end{array}$ \\
\hline 7. Author(s) & $\begin{array}{l}\text { 8. Pertorming Organization Report No. } \\
\text { E- } 1950\end{array}$ \\
\hline Robert F. Ide and G. Paul Richter & 10. Work Unit No. \\
\hline \\
\hline \multirow[t]{2}{*}{$\begin{array}{l}\text { NASA Lewis Research Center and Propulsion Laboratory } \\
\text { U.S. Army Research and Technology Laboratories (AVSCOM) } \\
\text { Cleveland, Ohio } 44135\end{array}$} & 11. Contract or Grant No. \\
\hline & 13. Type of Report and Period Covered \\
\hline 12. Sponsoring Agency Name and Address & Technical Memorandum \\
\hline $\begin{array}{l}\text { National Aeronautics and Space Administration } \\
\text { Washington, D.C. } 20546 \text { and U.S. Army Aviation } \\
\text { Systems Command, St. Louis, Mo. } 63120\end{array}$ & 14. Sponsoring Agency Code \\
\hline
\end{tabular}

15. Supplementary Notes

Robert F. Ide, Propulsion Laboratory, AVSCOM Research and Technology Laboratories, Lewis Research Center, Cleveland, Ohio 44135; G. Paul Richter, NASA Lewis Research Center. Prepared for the Twenty-second Aerospace Sciences Meeting sponsored by the American Institute of Aeronautics and Astronautics, Reno, Nevada, January 9-12, 1984.

16. Abstrect

A number of modern and old-style liquid water content (LWC) and droplet sizing instruments were mounted on a DeHavilland DHC-6 Twin 0tter and operated in natural icing clouds in order to determine their comparative operating characteristics and their limitations over a broad range of conditions. The evaluation period occurred during the 1982-1983 "icing season" from January to March, 1983. Time histories of all instrument outputs were plotted and analyzed to assess instrument repeatability and reliability. Scatter plots were also generated for comparison of instruments. The measured LWC from four instruments differed by as much as 20 percent. The measured droplet size from two instruments differed by an average of three microns. The overall effort demonstrated the need for additional data, and for some means of calibrating these instruments to known standards.

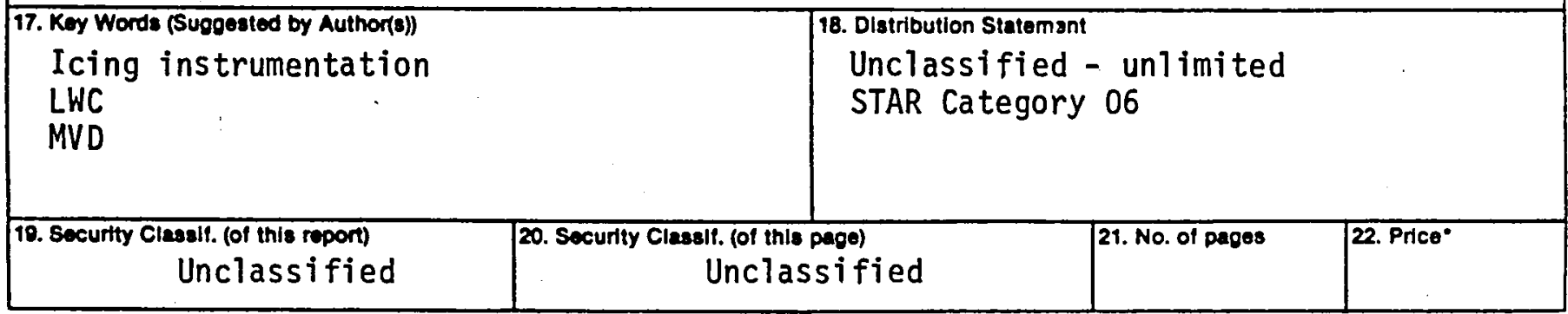


National Aeronautics and

Space Administration

Washington, D.C.

20546

Official Business

Penalty for Private Use, $\$ 300$
SPECIAL FOURTH CLASS MAIL

BOOK.

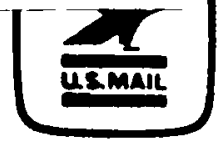

Postage and Fees Paid National Aeronautics and Space Administration NASA-451 